\title{
Emisi Metana dari Pengelolaan Kotoran Ternak di Yogyakarta - Inventarisasi
}

\section{Methane Emissions from Manure Management of Livestock in Yogyakarta-Inventory}

\author{
A. Hervani* dan M. Ariani \\ Balai Penelitian Lingkungan Pertanian, Pati, Jawa Tengah - 59182 \\ *E-mail: anggrihervani@yahoo.com
}

(Diterima: 21 Agustus 2019; Disetujui: 29 September 2019)

\begin{abstract}
ABSTRAK
Penelitian ini bertujuan untuk memberikan informasi secara berkala mengenai tingkat, status, dan kecenderungan emisi metana dari pengelolaan kotoran ternak di Yogyakarta. Penelitian ini merupakan penelitian desk study dengan cara melakukan inventarisasi GRK menggunakan Intergovernmental Panel on Climate Change (IPCC) Guidelines 2006. Penelitian dilaksanakan dengan mengumpulkan data aktivitas ternak provinsi Yogyakarta pada bulan November tahun 2016 sebagai sumber emisi GRK, serta penetapan faktor emisi berdasarkan IPCC Guidelines 2006. Data aktivitas didapatkan dari data statistik provinsi Yogyakarta. Inventarisasi emisi gas rumah kaca dari pengelolaan kotoran ternak di Yogyakarta menggunakan Tier 1 dari IPCC Guidelines. Hasil penelitian menunjukkan bahwa emisi terbesar dari pengelolaan kotoran ternak di Yogyakarta dari ternak unggas yaitu ternak ayam ras pedaging yang menyumbang $37 \%$ diikuti ayam buras sebesar $24 \%$, ayam ras petelur sebesar $20 \%$ dan itik sebesar $3 \%$. Sedangkan emisi dari ternak mamalia seperti sapi potong, sapi perah, kuda, kerbau, kambing, domba dan babi menyumbangkan emisi metana yang rendah terhadap total emisi metana dari pengelolaan kotoran ternak di Yogyakarta.
\end{abstract}

Kata kunci: emisi, inventarisasi, penglolaan kotoran

\section{ABSTRACT}

The research aims to provide regular information on the level, status, and trends of changes in methane emissions from manure management in Yogyakarta. This research is a desk study by conducting GHG inventories using the Intergovernmental Panel on Climate Change (IPCC) Guidelines 2006. The research was conducted by collecting the activity data of livestock at Yogyakarta province in November 2016 as a source of GHG emissions, as well as the determination of emission factors based on IPCC Guidelines, 2006. The activity data were obtained from the statistical data of Yogyakarta province. Inventory of greenhouse gas emissions from manure management in Yogyakarta using Tier 1 of the IPCC Guidelines. The results showed that the largest emissions from manure management in Yogyakarta come from poultry which accounted for $37 \%$ of total methane emissions from broilers, native chicken accounted for $24 \%$ of methane emissions, layer accounted for $20 \%$ and ducks accounted for $3 \%$. While, for mammals livestock likes beef cattle, dairy cattle, horses, buffalo, goats, sheep and swine have low contribution on methane emissions from manure management in Yogyakarta.

Keywords: emissions, inventory, manure management

\section{PENDAHULUAN}

Sektor pertanian tanaman pangan dan peternakan sebagai sektor yang berkontribusi utama dalam pemenuhan pangan ternyata juga sebagai salah satu sektor penyumbang emisi gas rumah kaca. Berdasarkan Kementerian
Lingkungan Hidup (2010), sektor pertanian merupakan sektor keempat yang berkontribusi menyumbangkan emisi gas rumah kaca ke atmosfer setelah sektor kehutanan, energi dan limbah. Dari total keseluruhan emisi gas rumah kaca, sektor pertanian berkontribusi sebesar 5\%. Dimana ada 5 (lima) kegiatan dalam sektor pertanian yang menjadi sumber 
gas rumah kaca yaitu 1) Peternakan, 2) Budidaya Padi sawah, 3) Pembakaran padang sabana, 4) pembakaran limbah pertanian dan 5) Tanah Pertanian (Intergovernmental Panel on Climate Change, 2006).

Inventarisasi gas rumah kaca (GRK) merupakan upaya untuk mendapatkan data dan informasi mengenai tingkat, status, dan kecenderungan perubahan emisi GRK secara berkala dari berbagai sumber emisi (source) dan penyerapnya (sink), termasuk simpanan karbon (carbon stock). Emisi GRK adalah lepasnya gas rumah kaca ke atmosfer pada area tertentu dalam jangka waktu tertentu (Republik Indonesia, 2011). Sektor pertanian menyumbangkan emisi gas rumah kaca utama yaitu metana dengan persentase $67 \%$ selanjutnya adalah $\mathrm{N}_{2} \mathrm{O} 30 \%$ dan $\mathrm{CO}_{2} 3 \%$. Sektor pertanian menyumbangkan emisi gas rumah kaca secara total mencapai 75.419,73 Gg pada tahun 2000. Lahan sawah dan tenak menyumbangkan masing masing $69 \%$ dan $28 \%$ terhadap emisi gas rumah kaca (Kementerian Lingkungan Hidup, 2009).

Emisi dari sektor peternakan berasal dari fermentasi enterik dan pengelolaan kotoran ternak. Sistem metabolisme ternak, khususnya untuk ternak ruminansia, merupakan sumber emisi gas rumah kaca. Selain melalui fermentasi enteric, metana juga dihasilkan dari proses oksidasi anaerob kotoran hewan. (Kementerian Lingkungan Hidup, 2012). Kotoran ternak selain bermanfaat sebagai penyumbang nutrisi pada tanah untuk pertumbuhan tanaman juga memiliki kontribusi negatif terhadap lingkungan berupa penurunan kualitas udara dari emisi ammonia dan metana, pencemaran tanah jika kotoran masih segar dan akan membuat tanah menjadi asam, dan masalah pencemaran air terkait dengan lepasnya nutrisi dan pathogen ke sumber air menyebabkan eutropikasi, membludaknya alga dan hipoksia (Sampat et al., 2018).

Perhitungan emisi metana dari kotoran ternak jauh lebih rumit dibandingakan dengan emisi metana dari ruminansia karena terkait dengan komposisi kotoran ternak, tipe fasilitas penyimpan kotoran ternak, sistem perkandangan, berapa kali hewan mengeluarkan kotoran dan suhu lingkungan merupakan contoh faktor yang sulit untuk di inventarisir (Hristov et al., 2017). Kemudian, pentingnya perhitungan inventarisasi emisi dari sektor peternakan harus dilakukan setiap tahun dengan tidak menggunakan faktor emisi yang konstan karena meningkatnya laju populasi ternak dan sistem manejemen perkandangan yang semakin maju (Yu et al., 2018).

Produksi gas metana dari seekor sapi dapat mencapai 49,80 kg/ekor/tahun, dengan dasar perhitungan bahwa energi gas metana yang terbentuk adalah $8 \%$ dari energi yang dikonsumsi ternak. Seekor ternak mengkonsumsi pakan sekitar 3\% dari bobotnya, sebagai contoh sapi dengan bobot $300 \mathrm{~kg}$ akan mampu mengkonsumsi $9 \mathrm{~kg} /$ hari bahan kering. Energi bruto pakan yang dionsumsi dalam satuan energi sebesar 10,46 $\mathrm{MJ} / \mathrm{kg}$ sehingga konsumsi enenrgi total adalah 94,14 MJ/hari. Dari energi bruto tersebut, 8\% akan terbentuk metana atau setara dengan 7,53 MJ yang sama dengan 2749 MJ per tahun (Haryanto dan Thalib, 2009). Beberapa penelitian menyebutkan bahwa dengan penambahan tannin dan saponin sebagai zat tambahan dalam pakan akan memodifikasi fermentasi dalam rumen yang selanjutnya akan mengurangi kehilangan energi, meningkatkan produktivitas hewan dan mengurangi emisi metana selama produksi ternak (Ugbogu et al., 2019). Tujuan dari penelitian ini adalah untuk memberikan informasi secara berkala mengenai tingkat, status dan kecenderungan perubahan emisi metana dari manejemen kotoran ternak di Yogyakarta.

\section{METODE}

Perhitungan emisi Gas Rumah Kaca (GRK) dalam rangka kegiatan inventarisasi GRK menggunakan Intergovernmental Panel on Climate Change-IPCC (2006) dengan cara pengumpulan data aktivitas ternak sumber emisi GRK, serta penetapan faktor emisi. 
Tabel 1. Faktor emisi ternak untuk menghitung manajemen kotoran ternak dengan Tier 1

\begin{tabular}{lc}
\hline \multirow{2}{*}{ Jenis Hewan } & Faktor Emisi \\
\cline { 2 - 2 } & $\left(\mathrm{kg} \mathrm{CH}_{4} /\right.$ ekor/th $)$ \\
\hline Sapi Perah & 31,00 \\
Sapi Potong & 1,00 \\
Kerbau & 2,00 \\
Kuda & 2,19 \\
Kambing & 0,22 \\
Babi & 7,00 \\
Domba & 0,20 \\
Itik & 0,20 \\
Ayam ras petelur & 0,20 \\
Ayam ras pedaging & 0,20 \\
Ayam buras & 0,20 \\
\hline
\end{tabular}

Sumber: Kementerian Lingkungan Hidup (2012)

Penetapan faktor emisi spesifik lokasi wilayah Yogyakarta masih belum tersedia. Faktor emisi yang tidak tersedia datanya, faktor emisi untuk melakukan inventarisasi mengacu pada IPCC. Sedangkan data aktivitas yang berupa data populasi ternak didapatkan dari data BPS.

Terdapat 3 (tiga) tingkat ketelitian "Tier" dalam metodologi inventarisasi untuk memperkirakan emisi gas rumah kaca. Tingkatan ketelitian dari "Tier dibedakan mulai dari penggunaan persamaam yang sederhana hingga kompleks. Tingkat sederhana menggunakan data default dari IPCC Guidelines 2006 hingga penggunaan data spesifik untuk sistem yang lebih kompleks.

Kegiatan inventarisasi metana dari manajemen kotoran ternak menggunakan Tier 1 karena belum adanya data spesifik di Yogyakarta. Tier 1 digunakan untuk perhitungan sederhana dimana persamaan dan nilai parameter standard untuk perhitungan dan asumsi (misalnya, faktor emisi dan perubahan simpanan karbon) telah tersedia dan dapat digunakan. Data aktivitas untuk Tier 1 biasanya berupa data kasar dan umum serta telah tersedia secara global (misalnya, data populasi ternak, pemakaian pupuk, statistik produksi pertanian, laju deforestrasi dan lainlain) (Kementerian Lingkungan Hidup, 2012).
Perhitungan yang digunakan menggunakan pedoman IPCC 2006 untuk menghitung emisi GRK adalah dengan mengalikan data aktivitas dengan faktor emisi sebagai berikut:

$$
\mathrm{E}=\mathrm{DA} \times \mathrm{FE}
$$

Dimana:

DA = Data aktivitas adalah besaran kuantitatif kegiatan atau aktivitas manusia yang dapat melepaskan dan/atau menyerap GRK.

$\mathrm{FE}=$ Faktor emisi adalah besaran emisi GRK yang dilepaskan ke atmosfer per satuan aktivitas tertentu (Kementerian Lingkungan Hidup, 2012).

Perhitungan emisi metana dari fermentasi enterik ternak digunakan persamaan berikut (IPCC, 2006):

$$
\text { Emisi }=\mathrm{EF}(\mathrm{T}) \times \mathrm{N}(\mathrm{T}) \times 10^{-6}
$$

Dimana:

Emisi $=$ Emisi metana dari manajemen kotoran ternak $\left(\mathrm{Gg} \mathrm{CH}_{4} \mathrm{yr}-1\right)$

$\mathrm{EF}(\mathrm{T})=$ Faktor emisi untuk populasi jenis ternak tertentu ( $\mathrm{kg} \mathrm{CH}_{4}$ head-1 yr-1)

$\mathrm{N}(\mathrm{T})=$ Jumlah populasi jenis/kategori ternak tertentu (Animal Unit) 
$\mathrm{T}=$ Jenis/kategori ternak

Untuk faktor emisi yang digunakan dalam rumus di atas menggunakan faktor emisi dari IPCC 2006 karena masuk katagori Tier 1 (Tabel 1).

Selain faktor emisi dan data aktivitas, untuk menghitung emisi metana dari manajemen kotoran ternak diperlukan nilai faktor koreksi. Faktor koreksi dimaksudkan untuk mengkoreksi umur ternak sehingga tidak semua ternak masuk ke dalam katagori umur muda atau tua. Berdasarkan Second National Communication (SNC), ada nilai faktor koreksi untuk ternak sapi potong, sapi perah dan kerbau secara berurutan yaitu 0,72 ; 0,75 dan 0,72 .

\section{HASIL DAN PEMBAHASAN}

Untuk menghitung emisi dari majanemen kotoran ternak, data yang digunakan adalah data populasi ternak Daerah Istimewa Yogyakarta yang dapat diunduh melalui alamat elektronik Badan Pusat Statistik. Data populasi ternak disajikan dalam Tabel 2. Pertumbuhan rata-rata populasi ternak di Yogyakarta sapmai tahun 2015 untuk sapi potong sebesar $3,54 \%$, sapi perah sebesar 2,08\%, kambing sebesar 3,03\%, kuda sebesar $6,62 \%$, domba sebesar $6,14 \%$, babi sebesar $4,96 \%$, itik sebesar $7,10 \%$, ayam ras petelur sebesar $9,19 \%$ dan ayam ras pedaging sebesar 5,17\%. Untuk ternak kerbau dan ayam buras mengalami rata rata penurunan populasi berurutan sebesar $8,75 \%$ dan $0,79 \%$.

Untuk ternak mamalia, yaitu sapi perah, sapi potong, kerbau, kuda, kambing, domba dan babi dari Gambar 1, dapat dilihat bahwa ternak sapi potong sebagai penyumbang emisi metana dari pengelolaan kotoran terbesar sebesar 0,232 $\mathrm{Gg} \mathrm{CH}_{4} /$ th sedangkan sapi perah, kuda, kerbau, kambing, domba, dan babi mengemisikan metana secara berurutan sebesar 0,$105 ; 0,004 ; 0,001 ; 0,09 ; 0,035$; $0,096 \mathrm{Gg} \mathrm{CH}_{4} /$ th.

Pada ternak unggas yang disajikan dalam Gambar 2, ternak ayam ras pedaging sebagai penyumbang emisi metana dari pengelolaan kotoran terbesar. Jika dibandingkan dengan ternak mamalia maka ternak unggas menyumbangkan emisi metana lebih besar. Emisi dari pengelolaan kotoran dari ternak itik, ayam ras petelur, ayam ras pedaging dan ayam buras secara berurutan sebesar 0,$119 ; 0,744 ; 1,367$ dan $0,887 \mathrm{Gg}$ $\mathrm{CH}_{4}$ /th.

Peningkatan emisi metana diproyeksikan dalam Gambar 3. Proyeksi emisi metana dari sektor peternakan tergantung pada peningkatan populasi ternak di Indonesia. Peningkatan emisi metana ini pada tahun 2030 diestimasikan akan menembus angka 1.732 ton/tahun (Permana et al., 2012). Peningkatan emisi metana dari kotoran ternak

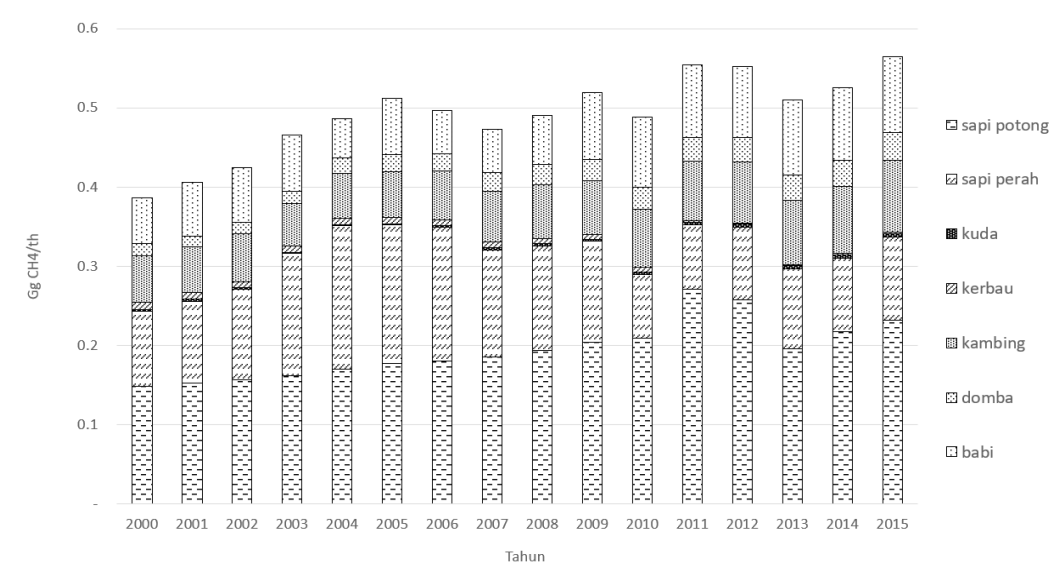

Gambar 1. Status emisi metana dari pengelolaan kotoran ternak mamalia 


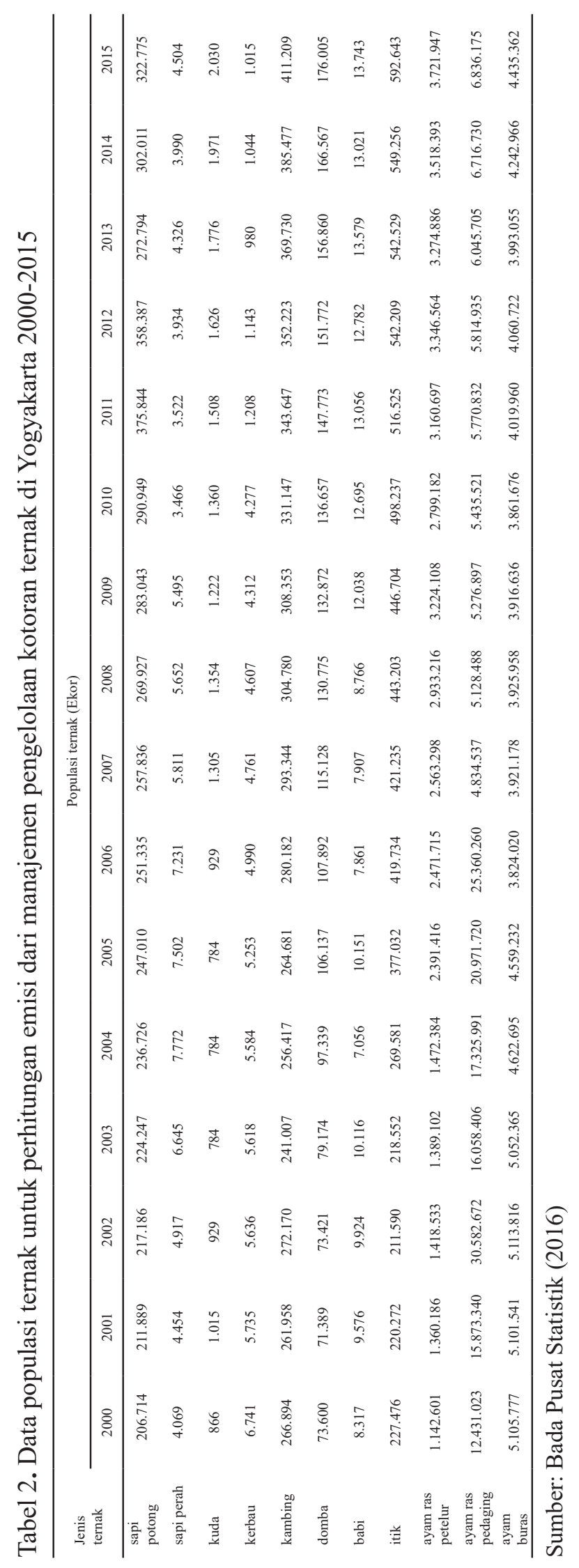




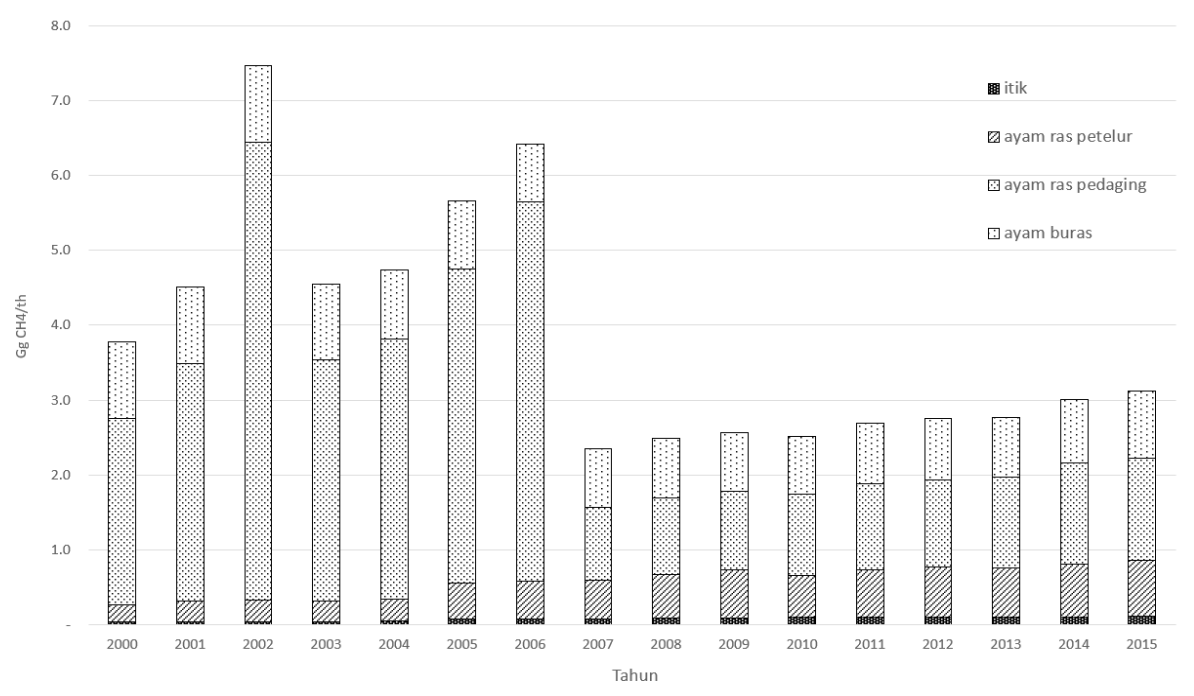

Gambar 2. Status emisi metana dari pengelolaan kotoran ternak unggas

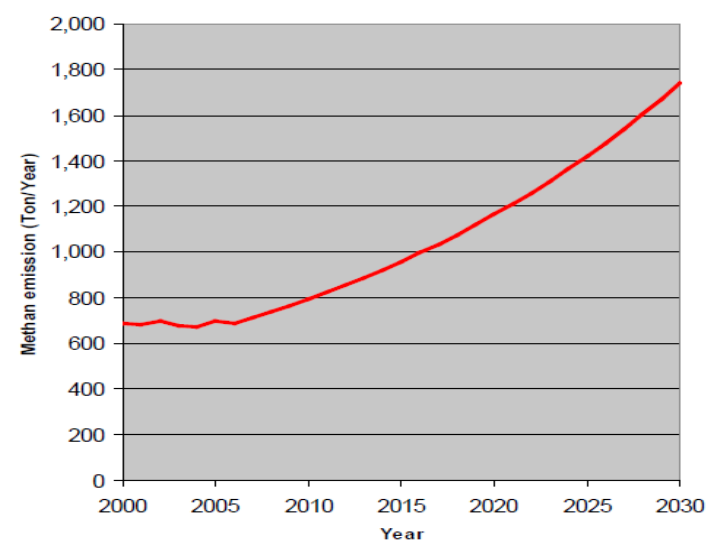

Gambar 3. Proyeksi emisi metana dari sektor peternakan(Permana et al., 2012)

akan semakin meningkat tidak hanya dari negara berkembang namun juga dari negara maju hanya saja jenis ternak penyumbang emisi dari kotoran ternak terbesar di negara maju adalah dari sapi potong, babi dan domba sedangkan untuk negara berkembang (study dari India) adalah ternak sapi, kerbau dan kambing (Patra, 2014).

Dari Gambar 4 diketahui bahwa emisi metana terbesar dari pengelolaan kotoran ternak di Yogyakarta pada tahun 2015 ada pada ternak unggas yaitu ternak ayam ras pedaging yang menyumbang $37 \%$ diikuti ayam buras sebesar $24 \%$, ayam ras petelur sebesar $20 \%$ dan itik sebesar 3\%. Emisi dari ternak mamalia seperti sapi potong, sapi perah, kuda, kerbau, kambing, domba dan babi menyumbangkan emisi metana yang rendah terhadap total emisi metana dari pengelolaan kotoran ternak di Yogyakarta secara berurutan sebesar 6\%, $3 \%, 0 \%, 0 \%, 3 \%, 1 \%$ dan 3\%. Sebagai upaya untuk mitigasi metana dan dinitrooksida dari kotoran ternak unggas, penggunaan lantai kayu yang beralas semen di kandang akan mengurangi emisi dibandingkan dengan lantai kayu yang beralaskan tanah (Ngwabie et al., 2018). Selain itu, pola pakan juga berkontribusi dalam penurunan emisi metana. Pengelolaan domba dengan pemberian pakan intensif sebesar $85 \%$ pakan konsentrat dan $15 \%$ padang penggemabalaan akan mengurangi 


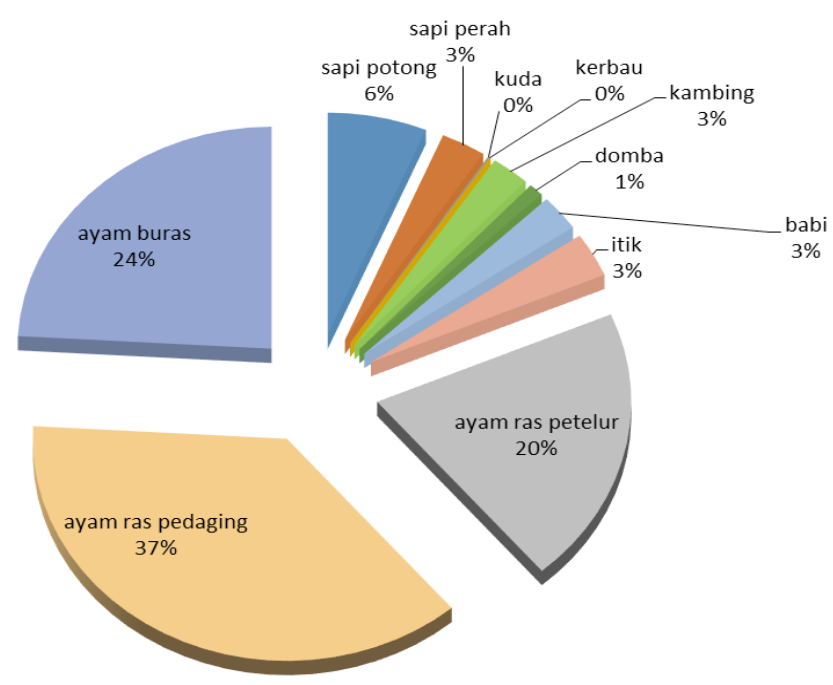

Gambar 4. Persentase ternak penyumbang emisi metana dari pengelolaan kotoran ternak di Yogyakarta tahun 2015

emisi metana sebesar hampir $90 \%$ jika dibandingan dengan padang penggembalaan dan pemberian pakan konsentrat yang jarang (Hijazi et al., 2014).

\section{KESIMPULAN}

Emisi metana terbesar dari pengelolaan kotoran ternak di Yogyakarta ada pada ternak unggas yaitu ternak ayam ras pedaging yang menyumbang $37 \%$ diikuti ayam buras sebesar $24 \%$, ayam ras petelur sebesar $20 \%$ dan itik sebesar 3\%. Sedangkan emisi dari ternak mamalia seperti sapi potong, sapi perah, kuda, kerbau, kambing, domba dan babi menyumbangkan emisi metana yang rendah terhadap total emisi metana dari pengelolaan kotoran ternak di Yogyakarta.

\section{UCAPAN TERIMA KASIH}

Penulis mengucapkan terima kasih kepada rekan-rekan di Laboratorium Gas Rumah Kaca Balai Penelitian Lingkungan Pertanian Titi Sophiawati, Jumari, Sri Wahyuni atas bantuannya dalam penyusunan makalah ini.

\section{DAFTAR PUSTAKA}

Badan Pusat Statistik (BPS). 2016. Data Populasi Ternak 2000 - 2015. Di unduh di www.bps.go.id tanggal 20 November 2016.

Haryanto, B. dan A. Thalib. 2009. Emisi metana dari fermentasi enterik: Kontribusinya secara nasional dan faktor-faktor yang mempengaruhinya pada ternak. WARTAZOA Vol. 19 No. 4 Th. 2009. 157-165.

Hijazi, O., W. Berg., S. Moussa., C. Ammon., $\mathrm{K}$. von Bobrutzki, and R. Brunsch. 2014. Comparing methane emissions from different sheep-keeping systems in semiarid regions: A case study of Syria. Journal of the Saudi Society of Agricultural Sciences. 13(2): 139-147.

Hristov, A. N., M. Harper., R. Meinen., R. Day., J. Lopes., T. Ott, and C. A. Randles. 2017. Discrepancies and uncertainties in bottom-up gridded inventories of livestock methane emissions for the contiguous United States. Environmental Science \& Technology. 51(23): 13668-13677.

Intergovernmental Panel on Climate Change 
(IPCC). 2006. IPCC Guidelines for National Greenhouse Gas Inventories - A primer, Prepared by the National Greenhouse Gas Inventories Programme (eds). IGES, Japan.

Kementrian Lingkungan hidup (KLH). 2009. Summary for Policy Makers : Indonesia Second National Communication Under The United Nation Framework Convention on Climate Change (UNFCCC). Jakarta. November 2009.

Kementrian Lingkungan Hidup (KLH). 2010. Indonesia Second National Communication. Under The United Nations Framework Convention on Climate Change (UNFCCC), Jakarta.

Kementrian Lingkungan Hidup (KLH). 2012. Pedoman Penyelenggaraan Inventarisasi Gas Rumah Kaca Nasional. Buku II Volume 3 Metodologi Perhitungan Tingkat Emisi Dan Penyerapan Gas Rumah Kaca Kegiatan Pertanian, Kehutanan, Dan Penggunaan Lahan Lainnya. Kementrian Lingkungan Hidup Press.

Ngwabie, N. M., A. N. Acobta., V. E. Manga, dan A. C VanderZaag. 2018. Emission factors of greenhouse gases from layer and broiler barns in Cameroon. Atmospheric Environment. 176: 54-59.

Permana., Suryahadi, and Boer. 2012. Inventory and mitigation for methane emissions from livestock in Indonesia. The $10^{\text {th }}$ Workshop on GHG Inventories in Asia (WGIA10). Vietnam, Juli 10-12
2012.

Republik Indonesia. 2011. Peraturan Presiden Republik Indonesia Nomor 71 tahun 2011 tentang penyelenggaraan inventarisasi gas rumah kaca. Lembaga Negara RI tahun 2011, Jakarta: Sekertariat Kabinet Republik Indonesia.

Patra, A. K. 2014. Trends and projected estimates of GHG emissions from Indian livestock in comparisons with GHG emissions from world and developing countries. Asian-Australasian journal of animal science. 27(4): 592.

Sampat, A. M., G. J Ruiz-Mercado, and V. M Zavala. 2018. Economic and environmental analysis for advancing sustainable management of livestock waste: A Wisconsin Case Study. ACS Sustainable Chemistry \& Engineering. 6(5): 6018-6031.

Ugbogu, E. A., M. M Elghandour., V. O. Ikpeazu., G. R. Buendía., O. M. Molina., U. O. Arunsi, and A. Z. Salem. 2019. The potential impacts of dietary plant natural products on the sustainable mitigation of methane emission from livestock farming. Journal of Cleaner Production. 213: 915-925.

Yu, J., S. Peng., J. Chang., P. Ciais., P. Dumas., X. Lin, and S. Piao. 2018. Inventory of methane emissions from livestock in China from 1980 to 2013. Atmospheric Environment. 184: 69-76. 